\title{
FINANCIAL UNITY OF THE WORLD AS AN ORGANIC PART OF GLOBALIZATION
}

\author{
Iryna Honcharenko ${ }^{1}$, Inna Servatynska ${ }^{2}$ \\ Cherkasy State Technological University, Ukraine
}

\begin{abstract}
The purpose of the paper is to determine the current features and phases of the formation of the financial unity of the world as an organic component of globalization and to identify the features of financial globalization in this context. Methodology. The list of the research methods of the subject under consideration includes the monographic method, analysis, techniques of the abstract-logical method, etc. Results. The urgency of the article is that the development and spread of globalization processes is a necessity to study the processes of forming a financial unity on a global scale, as a phenomenon that can have both positive and negative consequences. It is proved that the financial unity of the world is an integral part of globalization. The stages of formation of the financial unity of the world are determined. The positive and negative consequences are specified. Despite the assumption about possible negative manifestations of the financial unity of the world, acceleration of its offensive in the final, perfect form will allow providing significant advantages for global economic development. Practical implications. The main idea of the article was to justify the expediency of providing and using the financial unity as the instrument for development taking into account the prospects of globalization for national, regional economics, enterprises, and communities. Value/originality. The conducted research allowed highlighting the positive and negative effects of financial unity and financial globalization, as its manifestation, in the global economic system as important characteristics of the evolution and the current state of world financial architecture.
\end{abstract}

Key words: globalization, financial globalization, financial market, single currency, financial calculations.

JEL Classification: G22, F36, G11

\section{Introduction}

The essential features of the development of modern financial systems of different countries are their tendency to unite in the framework of international financial flows, development of common approaches to the allocation of financial resources, the emergence of supranational forms of financial intermediation etc. All these factors are an integral element of globalization, which has different manifestations in the economic sphere, and now it is found in the convergence of the economies of many states. Financial globalization is triggered by the growth of financial flows that can have negative consequences, which were manifested in the global financial crises destroying the financial architecture of the world. Thus, it helped it recover in new, more viable forms. The development of globalization processes needs further studying of processes of the fiscal unity formation on a global scale, as a phenomenon that can have both positive and negative consequences.

Target setting. In general, the effects of financial globalization have not been fully defined yet. Virtually

Corresponding author:

${ }^{1}$ Department Finance, Cherkasy State Technological University.

E-mail: irynahoncharenko@gmail.com

${ }^{2}$ Department Finance, Cherkasy State Technological University.

E-mail: i.servatynska@chdtu.edu.ua there is no formal empirical information confirming the often-quoted assertion that the financial globalization was a cause of the financial crises that occurred in the world in the last three decades. However, reliable evidence on the macroeconomic benefits of financial liberalization has not been obtained. Therefore, it is necessary to designate the positive and negative effects of the financial unity and financial globalization, as its manifestation in the global economic system in the form of the important characteristics of the evolution and current state of the global financial architecture.

\section{Results of previous researches}

The issue of globalization and, in particular, the financial aspect contained in the basis of the fiscal unity of the world, is revealed in the works of many local researchers, such as D. Y. Mamotenko (Mamotenko, 2009) who explores the globalization of international financial markets, V. V. Kuleshov (Kulishov, 2013) who specifies the nature and implications of financial globalization, V. S. Lukyanov (Lukyanov, 2013) who 
defines the basic imperatives and the crisis management mechanisms of the globalization of national financial systems, N. M. Ukhnal (Ukhnal, 2015) who studies the specific features of development of international financial centres in conditions of globalization of the financial system, V.V. Zhuravel (Zhuravel, 2010) who underlines the features of globalization of the world financial system et al. In foreign publications, issues of the studied subjects in certain aspects are investigated in sources (Sheffield, Korotayev \& Grinin, 2013; Schmukler, 2004; Rousseau \& Sylla, 2001; Prasad, Shang-Jin \& Kose, 2003). Due to the analysis of the mentioned above works including the author's works (Honcharenko \& Berezina, 2016; Berezina, Tkachenko, 2017), it is possible to make a conclusion. Contemporary manifestations of the world financial unity, such as the emergence of digital currencies, some of which tend to get the status of the future single currency with both advantages and life-threatening impacts on economic security on a global scale are still remain unexplored.

The objective of the study is to identify current characteristics and the gradual formation of the world fiscal unity as an integral component of globalization, and the establishment of specific features of financial globalization in this context.

\section{Stages of development of the world financial unity}

Globalization accompanies the development of all spheres of modern life and is traced in the evolution in different directions. The convergence of cultures, political trends and attitudes, completion of construction of a sole information space on the basis of the newest technologies of storage and data access, intensification of educational and scientific exchange, the high mobility of the inhabitants of the planet, and the formation of a single world economic system proves conclusively that the world is transforming into the area, where goods, services, information, capital, and other resources are transferred and new ideas circulate freely together with their carriers and proponents, providing the necessary conditions for the development of supranational structures and international institutions, as well as establishing their close collaboration. Globalization involves the formation of a unified international legal, cultural, informational, economic, and hence financial space. Undoubtedly, the process of financial unity will play a vital role in the global economy of our time, providing a sufficiently powerful impetus to the creation of an entirely new system of financial relations.

Let us consider the stages, according to which the financial unity of the world occurs, Table 1 .

The financial unity of the world is manifested in the formation of a single financial system, characterized by common dominant sources of financial resources, high level of interconnection of financial flows, redistribution of funds between states, unions of states, regions, industries to provide the necessary financial support and as a consequence, economic development. The principle of unity of the financial system is implemented in the mechanism of integration of financial plans and balance sheets developed at all levels of governance of the global economy.

Qualitative development of the financial sector has become a prerequisite for the integration of financial systems of individual countries into the global financial space and its status and level of architecture is one of the main factors that determine the magnitude of the financial growth and benefits that are expressed in maintaining stability, which can provide financial globalization. The higher the level of financial sector development of the state, the more benefits the country will receive from the proceeds of capital in the form of

Table 1

\section{Stages of development of the world financial unity}

\begin{tabular}{|c|l|}
\hline Stages & \multicolumn{1}{c|}{ Specific features of the stage } \\
\hline Stage 1 & $\begin{array}{l}\text { Establishing currency exchange rates, the formation of currency baskets, making a monetary exchange, establishment of financial } \\
\text { relations between states }\end{array}$ \\
\hline Stage 2 & $\begin{array}{l}\text { The rate to the convergence of financial markets; financial institutions from different countries such as product lines, which } \\
\text { allowed financial intermediaries of some state series; penetration of foreign capital in the regional financial markets }\end{array}$ \\
\hline Stage 3 & $\begin{array}{l}\text { The creation of international financial companies, expanding their branch networks around the world, creating a system of } \\
\text { supranational regulators of financial relations, origins of the global financial market }\end{array}$ \\
\hline Stage 4 & $\begin{array}{l}\text { Enhancing the authority of international financial organizations, granting them the right to solve the financial problems of the } \\
\text { global scale and influence on the national financial system }\end{array}$ \\
\hline Stage 5 & $\begin{array}{l}\text { The development of payments using on the basis of electronic systems, facilitation of the access to financial products and } \\
\text { services, increase in demand through international programs for the improvement of financial literacy of the population }\end{array}$ \\
\hline Stage 6 & $\begin{array}{l}\text { (Current status) the Gradual levelling of the status of national currencies, distinguishing several currencies accepted for } \\
\text { calculation in most countries and can claim the status of global currency; the emergence of virtual, digital currency, completion } \\
\text { of formation of the global financial market, and building of its architecture }\end{array}$ \\
\hline Stage 7 & $\begin{array}{l}\text { (In the future) the use of a single digital world currency, the same conditions for the licensing and activities of financial } \\
\text { institutions, the same rules and rates for the use of financial products and services, the ability to use them anywhere in the world } \\
\text { in selected financial companies }\end{array}$ \\
\hline
\end{tabular}

Resource: Compiled by the authors 
financial growth. At the same time, the dependence on foreign financial flows could cost the state its financial stability, make vulnerable to large-scale financial crises.

At the same time, in developing countries without their own high-performance of the financial sector, the sudden change of direction of financial flows can initiate or exacerbate the cycles of financial ups and downs. In addition, the mismatch of the financial policy between the requirements of the time, the low level of financial regulation, excessive liberalization of the domestic financial sector are the main causes of many crises that may be associated with financial integration, but in fact could be offset under the condition of the national financial services markets of a sufficient amount of foreign capital.

\section{Mainstreams of financial unity and international financial market development}

Financial world unity is expressed primarily in the formation of a single financial market. In recent decades, the global (international) financial market has been widely developed and is currently playing a leading role in the global economic system. The trends in the development of a single financial market are the following: globalization, internationalization, institutionalization, disintermediation, the increased level of international competition, integration, convergence, informatisation, computerization, and concentration of world markets.

The globalization of the international financial market is reflected in the increase of its share in the operations of providing active and passive forms of financial services by residents of different countries. The internationalization of the international financial market means that the high level of diversification of activity of economic entities in different regions of the world makes it impossible to determine their nationality. Integration of the international financial market is one of the most notable trends of the global financial system. Integration processes contribute to the increasing mobility of financial capital and reducing transaction costs in the use of financial products and services. Convergence of the international financial market and its individual segments is a process similar in its substantive essence with the integration, which consists in the gradual disappearance of borders between the national sectors of the international financial market. The process of institutionalization of the international financial market is reflected in the strengthening of the role of financial institutions in the global financial architecture.

Disintermediation - "the leaching of mediation" has become another noticeable trend in the development of the international financial market and had a significant meaning for the integration processes in the financial sector. It means the elimination of financial intermediaries (brokers, banks) from transactions between borrowers and lenders or buyers and sellers of financial products and services in the market, allowing both sides of a financial transaction to reduce their costs by refusing to pay commissions and other fees.

Increased competition over thelast twentyyearsamong global companies and financial institutions has led, on the one hand, to the improvement of the functioning of the international financial market, and on the other, to the growth of requirements for financial institutions with respect to their economic efficiency and financial security. Thus, the only financially stable and profitable companies with a wide network of branches and offices that have a recognizable brand, a good reputation and associate consumer financial services with reliability and stability, which provide them with a high level of customer confidence remain on the global financial market. The increased competition had an impact on the concentration of international financial market and its participants. Now the concentration occurs through the mechanisms of mergers and acquisitions, and these transactions are of a supranational, global character.

Computerization and informatisation are currently the main trends in the international financial market because its activities at the present stage are done using a computer and information technology. Their proliferation has resulted in increased use of financial products and services; it has enabled financial institutions to serve their clients in a single financial space. The participants in the international financial market make management, investment, and financial solutions based on sophisticated techniques of computer simulation.

The global financial market international financial centres, which were the largest cities on the planet, in countries where the concentration of financial flows was the most obvious coordinate their activities. The emergence of international financial centres is the requirement of time and opportunity for states to integrate into the modern global economic environment.

Finally, the financial world unity will not be achieved without the introduction of a single currency for service payments.

In 1988, economists predicted the emergence of a single world currency. Let us quote a fragment of the publication from the "Economist" magazine: "Thirty years from now, Americans, Japanese, Europeans, and people in many other rich countries, and some relatively poor ones will probably be paying for their shopping with the same currency. Prices will be quoted not in dollars, yen or D-marks but in, let's say, the phoenix. The phoenix will be favoured by companies and shoppers because it will be more convenient than today's national currencies, which by then will seem a quaint cause of much disruption to economic life in the last twentieth century" (Mamotenko, 2009). Given that the prophecy was made in 1988 for the thirty-year perspective, it should be realized in 2018, what makes this study even more relevant. 
At this point, USD can be called world currency with some conventions. Although, it isn't used in a number of countries. The international financial relations are based on the American dollar. This situation does not suit the government of a significant number of countries that understand that we should not allow one state to be emission centre of the whole world. The desire to introduce a single world currency is quite understandable. The supporters of the innovations propose to create a new instead of using an existing one at the moment. However, in any case, the country that will receive emission right will be in a better position than other participants in the global financial system. Therefore, it is advisable to assume that a new stage of fiscal centralization and globalization will be a single world of digital origin. It can be assumed that it will be similar to the bitcoin Blockchain, which for many has become a factor in the reliability of cryptocurrencies, proved to be beneficial for market regulators and authorities.

Opponents of cryptocurrencies claim that their significant drawback is the possibility to use outside the official financial accounts, i.e. for the needs of the shadow economy. However, if the authorities need to track transactions using bitcoin, due to the development of modern technologies and information systems, they will be able to do it, no matter how good the attackers will try to hide their actions. The prospect of anonymity while using cryptanalytic has not been completely proven. Thus, there is every reason to believe that central banks and international financial conglomerates will actively use bitcoin as a world currency. It will probably appear to be the mythical currency "Phoenix", which was foreseen in 1988 .
An incredible amount of capital invested by large financiers in the blockchain, support from central banks is a signal that the technology of the blockchain will form the basis for the currency system of a "new world order" and accelerate the onset of the financial unity of the world in its perfect form.

\section{Advantages and threats from the financial unity of the world and financial globalization}

What will the introduction of the single global currency on the globalization scale help achieve? Its use will allow avoiding sharp rate fluctuations of national currencies. And will contribute, therefore, to an active development of international economic relations (i.e. economic globalization).

This study determines the advantages and threats from the financial unity of the world and financial globalization (see Table 2), the occurrence of which, however, is inevitable, given the active development of globalization processes in the world.

In spite of the suggestions regarding the possible negative effects of the financial unity of the world, accelerating its onset in a final, perfect form would provide significant benefits for the global economic development.

\section{Conclusions}

A study of trends and characteristics of the financial unity of the world as an integral component of globalization has led to the following conclusions.

1. The world financial unity has been proven to be an integral part of globalization. The convergence

Table 2

Positive and negative effects of the onset of the world financial unity and financial globalization

\begin{tabular}{|c|c|}
\hline Positive consequences & Negative effects \\
\hline $\begin{array}{l}\text { The free exchange of financial assets, financial products and services } \\
\text { in any country in the world }\end{array}$ & $\begin{array}{l}\text { The possibility to raise prices for financial products and services by } \\
\text { means of the financial oligopoly of international companies }\end{array}$ \\
\hline $\begin{array}{l}\text { Cost reduction and financial services due to the tax-free currency } \\
\text { exchange }\end{array}$ & Leaving the financial market for small business financial forms \\
\hline $\begin{array}{l}\text { The increase in the rate of financial services through the use of single } \\
\text { settlement and payment systems }\end{array}$ & $\begin{array}{l}\text { Total control of international financial organizations of the } \\
\text { functioning of national financial systems }\end{array}$ \\
\hline $\begin{array}{l}\text { Levelling of the cost of issuing paper money provided the use of a } \\
\text { single digital currency (cryptanalytic) }\end{array}$ & $\begin{array}{l}\text { The use of cryptocurrencies with criminal intent through the use of } \\
\text { information and computer technology }\end{array}$ \\
\hline $\begin{array}{l}\text { The introduction of the unified rules of conducting the financial } \\
\text { business, single standards and requirements for the quality of } \\
\text { financial products and services }\end{array}$ & $\begin{array}{l}\text { The increasing number of financial frauds and economic crimes with } \\
\text { the use of computer technology }\end{array}$ \\
\hline $\begin{array}{l}\text { The ability to control all cash flows to minimize the shadow } \\
\text { economy, funding of terrorism and money laundering }\end{array}$ & $\begin{array}{l}\text { The possibility of destruction of the entire global financial system } \\
\text { and its architecture by a large-scale hacker attack }\end{array}$ \\
\hline Improving financial literacy of the world's population & $\begin{array}{l}\text { The destruction of the national financial diversity of banknotes, } \\
\text { coins and other means of calculation }\end{array}$ \\
\hline $\begin{array}{l}\text { The increase in demand for financial products and services, the } \\
\text { ability to use them to increase the level of welfare of the population } \\
\text { of the world }\end{array}$ & $\begin{array}{l}\text { The redistribution of financial resources in favour of international } \\
\text { financial centres, favouritism in the allocation of investment capital }\end{array}$ \\
\hline Facilitating the access to investment resources on the capital market & $\begin{array}{l}\text { The inability to withstand the global financial crises by the means of } \\
\text { national financial systems }\end{array}$ \\
\hline
\end{tabular}

Resource: Compiled by the authors 
of various political, cultural, economic trends, the formation of unions of states, common information space, supranational markets of goods and services necessitated the exchange of financial flows, unification of models of financial intermediation, build the international financial architecture, the emergence of universal means of payment of digital currency. Financial globalization has expanded the boundaries of the capital markets, has ensured their smooth movement to meet the financial requirements and implementation of financial interests both at the macro- and micro-level. Further economic development on a global scale would be impossible without the introduction of unified norms and rules of functioning of the financial system.

2. Financial unity of the world in its modern form took place in several stages. The establishment of foreign currency exchange rates took place on the first one; the course towards financial markets started on the second one; the third included the creation of international financial companies, the noticeable increase in the authority of international financial organizations happened in the fourth stage; the growth of cashless payments took place on the fifth stage; the present time gradual levelling of the status of the national currency, the completion of the formation of the global financial market and building its architecture was on the sixth stage; the last, seventh stage is expected to implement and use a single digital world currency.

3. Financial globalization can have both positive and negative effects on the global economic order. However, the onset of the financial unity of the world is inevitable because this phenomenon is an integral consequence of the quality of the upcoming transformation of the world economic plane. Therefore, the level of international financial institutions should develop a list of strategic directives and imperatives to avoid and minimize the threats that may result in the further process of unification of the financial system to ensure a high level of global financial and economic security in the future.

\section{References:}

Berezina, O.Y. \& Tkachenko, Yu.V. (2017) Hlobalne partnerstvo v paradyhmi staloho rozvytku: osvita, tekhnolohii, innovatsii [Global partnership in the sustainable development paradigm: education, technology, innovation]: monograph. Cherkasy: Chabanenko Yu.A., 524 p.

Get Ready for the Phoenix Source (1988) Economist. vol. 9, 306, pp. 9-10.

Honcharenko, I. \& Berezina, O. (2016) Cooperation of the bank and insurance business as an effective model: history and present day. Organizational and economic mechanisms of development of the financial system: collective monograph / edited by M. Bezpartochnyi. Riga : Landmark SIA, pp. 83-92.

Kulishov, V.V. (2013) Finansova hlobalizatsiya: sutnist i naslidky [Financial globalization: the essence and consequences] Business Inform, vol. 3, pp. 303-307.

Lukyanov, V.S. (2013) Hlobalizatsiya natsionalnykh finansovykh system: bazovi imperatyvy ta antykryzovi mekhanizmy [Globalization of National Financial Systems: Basic Imperatives and Anti-crisis Mechanisms] Finance of Ukraine. vol. 9, pp. 60-67.

Mamotenko, D.Yu. (2009) Hlobalizatsiya mizhnarodnykh finansovykh rynkiv [Globalization of International Financial Markets]. Humanitarian Bulletin of Zaporizhzhya State Engineering Academy, vol. 39, pp. $229-237$.

Prasad K.R., Shang-Jin W. \& Kose M.A. (2003) Effects of Financial Globalization on Developing Countries: Some Empirical Evidence. Available at: https://www.imf.org/external/np/apd/seminars/2003/newdelhi/prasad.pdf (accessed 10 April 2018).

Rousseau P.L. \& Sylla R. (2001) Financial Systems, Economic Growth, and Globalization. Globalization in Historical Perspective. - University of Chicago Press, pp. 373-415.

Sheffield J., Korotayev A. \& Grinin L. (2013) Globalization: Yesterday, Today, and Tomorrow. USA [in English].

Schmukler S.L. (2004) Benefits and Risks of Financial Globalization: Challenges for Developing Countries. Available at: http://siteresources.worldbank.org/DEC/Resources/BenefitsandRisksofFinancialGlobalizationSchmukler. pdf (accessed 10 April 2018).

Ukhnal, N.M. (2015) Osoblyvosti rozvytku mizhnarodnykh finansovykh tsentriv v umovakh hlobalizatsiyi finansovoyi systemy [Features of the Development of International Financial Centers in the Conditions of the Globalization of the Financial System] Scientific Papers NDFI, vol. 2, pp. 17-32.

Zhuravel, V.V. (2010) Osoblyvosti hlobalizatsiyi svitovoyi finansovoyi systemy [Features of Globalization of the World Financial System] Bulletin of Kharkiv National University named after V.N. Karazin. Series: Economics, vol. 911, pp. 133-137. 